http://dx.doi.org/10.11646/zootaxa.3682.3.9

http://zoobank.org/urn:lsid:zoobank.org:pub:8E004D65-716D-4C01-866D-675991A56002

\title{
The assignment of Prodidactidae to Hyblaeoidea, with remarks on Thyridoidea (Lepidoptera)
}

\author{
LAURI KAILA ${ }^{1,4}$, MARC E. EPSTEIN ${ }^{2}$, MARIA HEIKKILÄ ${ }^{1} \&$ MARKO MUTANEN $^{3}$ \\ ${ }^{1}$ Finnish Museum of Natural History, Zoology Unit, P. O. Box 17, FI-00014 University of Helsinki, Finland. \\ E-mail: lauri.kaila@helsinki.fi; maria.heikkila@helsinki.fi \\ ${ }^{2}$ California Dept. of Food \& Agriculture, Plant Pest Diagnostic Laboratory, 3294 Meadowview Road, Sacramento, CA 95832-1448, \\ U.S.A.E-mail: marc.epstein@cdfa.ca.gov \\ ${ }^{3}$ Biodiversity Unit, Department of Biology, P.O. Box 3000, FI-90014 University of Oulu, Finland. E-mail: marko.mutanen@oulu.fi \\ ${ }^{4}$ Corresponding author
}

\begin{abstract}
We examine the systematic position of the lepidopteran family Prodidactidae Epstein and Brown, 2003, which includes the single species Prodidactis mystica (Meyrick). We provide details on a morphological trait of the adult male hindcoxa that appears to link Prodidactidae with Hyblaeidae. This putative relationship is consistent with molecular data derived from five genes. Based on morphological and molecular evidence, we place Prodidactidae in Hyblaeoidea. Moreover, the apex of the larval spinneret is similarly modified in these families and in Thyrididae. This modification is unknown in other Lepidoptera and may prove to be a synapomorphy linking Thyridoidea and Hyblaeoidea. As the latter is not fully congruent with published molecular studies, we refrain from suggesting sister group position for Thyridoidea and Hyblaeoidea.
\end{abstract}

Key words: Apoditrysia, Obtectomera, phylogeny, systematics

\section{Introduction}

Recent advances in the molecular systematics of Lepidoptera (e.g., Mutanen et al. 2010; Regier et al. 2013) have shed new light on the previous morphology- and tradition-based higher classification of Lepidoptera. However, much of the molecular evidence is controversial and preliminary. The "backbone" phylogeny of the order, i.e. the interrelationships of superfamilies of the Apoditrysia, the large clade of more advanced Lepidoptera, remains insufficiently resolved, either by traditional morphological (see Kristensen 1998) or molecular evidence. As a result of the recent attention focused on the phylogeny of Lepidoptera, several new patterns of relationships have been revealed, and some preliminary adjustments to the classification have been suggested. Some of the more compelling ones are incorporated in the latest classification of the Lepidoptera by Nieukerken et al. (2011). Family- and superfamily-level studies based primarily on molecular evidence are now being published regularly, e.g., Bombycoidea (Zwick 2006, 2008, Zwick et al. 2011), Gracillariidae (Kawahara et al. 2011), Gelechioidea (Kaila et al. 2011), Gelechiidae (Karsholt et al. 2013), Geometridae (Sihvonen et al. 2011), Noctuoidea (Zahiri et al. 2011, 2012, 2013), butterflies (Wahlberg et al. 2005 and references therein, Heikkilä et al. 2012), Pyraloidea (Regier et al. 2012), Tortricoidea (Regier et al. 2012), and Yponomeutoidea (Sohn et al. 2013). Only rarely have morphological characters been incorporated into these DNA-based analyses, and even then they have been applied to resolve relationships of putatively close groups (e.g., Zwick 2006, Heikkilä et al. 2012, Simonsen et al. 2012, Zahiri et al. 2013). Other changes in the classification of the order based on molecular evidence, or its application together with morphological evidence, are the exclusion of Douglasiidae from Gracillarioidea and its placement in the more 'advanced' Apoditrysia, though incertae sedis (Mutanen et al. 2010, Kawahara et al. 2011); the transfer of Lypusidae from Tineoidea to Gelechioidea (Heikkilä \& Kaila 2010, Kaila et al. 2011); and the separation of Millieriidae from Choreutidae and its transfer to Apoditrysia, incertae sedis (Rota 2011, Rota \& Kristensen 2011). 
As the molecular evidence is still far from resolving interrelationships of superfamilies of Apoditrysia in a convincing manner, support from morphology remains an obvious, yet underrated source of further insight. This is curious because until a decade or so ago, morphology was almost the single source of information upon which the lepidopteran phylogeny was based (e.g., Minet 1991, Kristensen 1998).

One lepidopteran taxon that has defied confident systematic placement is the South African moth Prodidactis mystica (Meyrick). The monotypic genus has historically been assigned to Tortricidae (Meyrick 1918, 1921), Yponomeutidae (Meyrick 1930), and Limacodidae (Janse 1964). After the discovery of the immature stages of the species by the late Neville Duke, Epstein and Brown (2003) noted that none of these family assignments was correct for the species. They found that the larval features would best match Crambidae (Pyraloidea), whereas a number of adult characters were in conflict with such a position. They provided a thorough review of significant characters of this taxon using the table by Heppner (1998: "Table 2: Family Character States"), along with the select families, i.e., Yponomeutidae, Tortricidae, Zygaenidae, Limacodidae, Immidae, and Crambidae, for comparison. As no satisfactory placement was found for Prodidactis, a new family, Prodidactidae, was proposed as an interim solution (Epstein \& Brown 2003). They noted that the adult has peculiarities such as the extremely reduced adult labial palpi and the elongate membranous lobe in the male hindcoxa. They considered these characters as autapomorphies for the newly proposed family.

The presence of a male coxal lobe, suggested to be an autapomorphy of Prodidactidae by Epstein and Brown (2003), caught the attention of the present authors, as a similar structure, called the saclike coxal process, had been proposed as an autapomorphy of the family Hyblaeidae by Koning and Roepke (1949). Curiously, this character is not mentioned for Hyblaeidae by Dugdale et al. (1998), even though they note another modification in the male hindleg to characterize this family: "male hindleg modified, with large concave coxal process into which tibial hair-pencil fits." The hind tibia of Hyblaea is indeed modified to form a swollen pocket where the conspicuous tibial hair-pencil may be placed (see Figs 1-3). However, this feature does not seem to be the one upon which Koning \& Roepke (1949) elaborated, and it may even be that Dugdale et al. (1998) confused these two characters, as they mention the modification to be in the coxa and characterize it as a lobe.

Because Epstein and Brown (2003) exhaustively elaborate why Prodidactis is unlikely a member of the families they considered (see above), our aim is to explore the possibility that Prodidactis is related to Hyblaeidae (Hyblaeoidea), a family that Epstein and Brown (2003) did not include in their analysis. We tabulated characters, including those used by Epstein and Brown (2003), to compare Prodidactidae and Hyblaeidae (Table 1).

There are a number of similarities, but also many differences, between Hyblaeidae and Prodidactidae. At this point, it should be noted that several of the characters considered by Epstein and Brown (2003) characterize Zygaenoidea where Prodidactis had been be placed by Janse (1964), and may not be relevant in the current context where this association has been rejected convincingly on the basis of larval morphology.
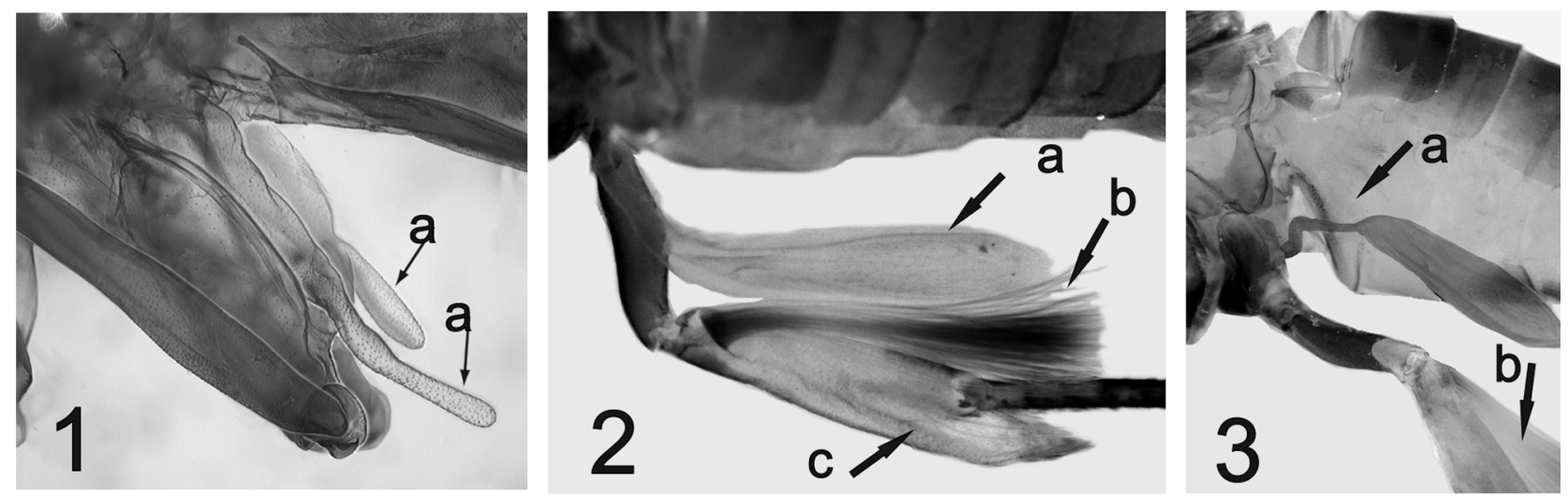

FIGURES 1-3. Hind coxae of denuded males of Prodidactis mystica (Meyrick) and Hyblaea puera (Cramer). Fig. 1: Hind coxa of P. mystica showing coxal processes (a). Photo courtesy of Marc Epstein and John W. Brown. The coxal processes on the P. mystica specimen photographed by Epstein and Brown (2003) are asymmetrical. We were unable to check whether this asymmetry is a general trait of the coxal processes of the species or a deformation of the individual examined. Unfortunately, the only male specimen of $P$. mystica we obtained for our examinations had only one of the two coxae intact, thus leaving the question about asymmetry unanswered. Fig. 2: Hind leg of a male H. puera treated in $\mathrm{KOH}$ solution showing large coxal process/sac (a); tibial hair-pencil (b); and enlargement of tibia (c). Fig. 3: Hind leg of a male H. puera, showing the inception point of the coxal process (a), and the tibial hair pencil (b). 
TABLE 1. Comparison of morphological characters of Hyblaeidae and Prodidactidae. Data of Prodidactis include those from Epstein and Brown (2003).

\begin{tabular}{|c|c|c|}
\hline & Prodidactidae & Hyblaea puera \\
\hline \multicolumn{3}{|l|}{ EGG } \\
\hline egg type & flat & flat \\
\hline \multicolumn{3}{|l|}{ LARVA } \\
\hline head partially retractile & present & absent \\
\hline spinneret with 4 globular lobes at apex & present & present \\
\hline L-group on $\mathrm{T} 1$ & bisetose & $\begin{array}{l}\text { bisetose [one larva examined trisetose } \\
\text { on one side] }\end{array}$ \\
\hline L-group on $\mathrm{T} 2 \& \mathrm{~T} 3$ & $\begin{array}{l}\text { L1 \& L2 on common lateral } \\
\text { pinaculum }\end{array}$ & $\begin{array}{l}\text { L1 \& L2 on common lateral } \\
\text { pinaculum }\end{array}$ \\
\hline legs with scalelike seta behind tarsal claw & present & absent \\
\hline D-group pinacula on $\mathrm{T} 2 \& \mathrm{~T} 3$ without setae & present & absent \\
\hline raised pinacula on thorax and abdomen & present & absent \\
\hline crochets & biordinal circle & bi/triordinal circle \\
\hline prolegs & short, A3-6, 10 & normal, A3-6, 10 \\
\hline $\mathrm{L} 1$ and $\mathrm{L} 2$ on abdomen & same pinaculum & same pinaculum \\
\hline anal fork & absent & absent \\
\hline BIOLOGY & exposed feeding late instars & feed in leaf shelters in all instars $* * *$ \\
\hline \multicolumn{3}{|l|}{ PUPA } \\
\hline general form & $\begin{array}{l}\text { "compact" (example available may be } \\
\text { shrivelled) }\end{array}$ & normal obtectomeran \\
\hline haustellum & present & present \\
\hline labial palpus & reduced & long and porrect \\
\hline maxillary palpus & present & present \\
\hline antenna length & extends to near FW apex & extends $2 / 3$ 's to FW apex*** \\
\hline eye & unsculptured & unsculptured \\
\hline dorsal spines & absent & absent \\
\hline cremaster & absent & present \\
\hline cocoon & present & present \\
\hline protrudes at emergence & no & no \\
\hline \multicolumn{3}{|l|}{ ADULT } \\
\hline vertex of head & smooth-scaled & smooth-scaled \\
\hline labial palpus & 3-segmented & 3-segmented \\
\hline maxillary palpus & 3-segmented & $3-4 * *$-segmented \\
\hline haustellum & naked & naked \\
\hline male antenna & filiform & filiform \\
\hline antennal pecten & absent & absent \\
\hline ocellus & absent & present* \\
\hline chaetosemata & absent & absent \\
\hline venation & heteroneurous & heteroneurous \\
\hline wing coupling & frenulate & frenulate \\
\hline FW pterostigma & absent & absent \\
\hline FW chorda & present & absent \\
\hline FW anal veins & $1 \mathrm{~A}+2 \mathrm{~A}$ stalked & not stalked \\
\hline
\end{tabular}

.......continued on the next page 
TABLE 1. (Continued)

\begin{tabular}{lll}
\hline & Prodidactidae & Hyblaea puera \\
\hline FW cell vein & absent & absent \\
HW pterostigma & absent & absent \\
HW cell vein & absent & absent \\
epiphysis & present & present \\
tibial spurs & $0-2-4$ & male 0-2-0/female 0-2-4 \\
pretarsal pulvillus & setiform outgrowth & setiform outgrowth \\
abdominal tympana & absent & absent \\
abdominal apodemes & tortricoid-type & tortricoid-type \\
male w/ hairpencil & coxal hairpencil present & tibial hairpencil present \\
male w/ membranous hind coxal lobes & present & present \\
\hline
\end{tabular}

*Koning \& Roepke (1949): absent; **Dugdale et al. (1998); ***Common (1990).

Larval characters are often homoplastic, at least to some extent. The larva of Prodidactis possesses features in common with some Crambidae (Epstein and Brown 2003), including the bisetose L group of T1 and the non-setabearing pinacula of abdomen. In most microlepidopterra, the $\mathrm{L}$ group of the prothorax is trisetose. However, the bisetose condition is found at least sporadically in Bucculatricidae and Gracillariidae (Gracillarioidea), Tortricidae (Tortricoidea), Momphidae (Gelechioidea), Epermeniidae (Epermenioidea), Alucitoidea, Carposinidae and Copromorphidae (Copromorphoidea), and in virtually all Crambidae and Pyralidae (Pyraloidea), Thyrididae (Thyridoidea), Hyblaeidae, Geometridae (Geometroidea) and Noctuoidea. These multiple occurrences weaken to some extent the systematic signal of this character. Though, when taxa with at least an occasional bisetose condition in the L group are plotted on the phylogenies of Mutanen et al. (2010) and Regier et al. (2013), there might be at least some phylogenetic signal grouping Hyblaeoidea + Prodidactis + Papilionoidea, or Hyblaeoidea + Prodidactis + Pyraloidea (also see Table 1 for the distribution of L setae on T2). The larvae of Lypusidae (Gelechioidea) also have non-seta-bearing plates (pinacula) on the abdomen, so this feature is somewhat homoplastic. Epstein and Brown (2003) noted and illustrated apical lobes in the spinneret that seem exceptional in Lepidoptera. We examined this trait across Lepidoptera, especially from representatives of groups that could be possibly related to Hyblaea on the basis of the molecular studies of Mutanen et al. (2010) and Regier et al. (2013): Carposinidae, Copromorphidae, Epermeniidae, Pterophoridae, Thyrididae, Papilionidae, Pieridae and most subfamilies of Pyraloidea. The larva of Callidulidae, putatively the sister of Hyblaea in the analysis of Regier et al. (2013), was not available. The modification of the spinneret was found to be present in Prodidactis, Hyblaea and the two representatives of Thyrididae examined: Aglaopus pyrrhata (Walker) (Striglininae) and Addaea subtessellata Walker (Siculodinae. This feature appears to be a unique trait linking Hyblaeidae, Prodidactis and Thyridoidea (Figs. 4-6).

There are several larval traits of Prodidactis not reported by Epstein and Brown (2003) (Figs. 7-14), and this is partially explained by the fact that they did not compare it with Hyblaeidae. The occurrence of a partially retracted head would have been obvious in comparing the two (Figs. 7, 8, 10,11). The pinacula on the thorax and abdomen in Prodidactis are also noticeably raised compared to those found in Hyblaea, though perhaps more similar to Thyrididae. Pinacula without setae on the dorsal thorax of Prodidactis, similar to those in some Crambidae, are not found in Hyblaea (Figs. 9, 12-14). Other features found in Prodidactis but not in Hyblaea include one scalelike seta on each leg behind the tarsal claw (Figs. 15-18). In addition, the legs are splayed out more horizontally and grouped nearer to the head, and the abdominal prolegs are shorter. These character systems perhaps relate to behavioral differences between the larvae. Hyblaea makes leaf shelters in all instars, whereas Prodidactis tends to feed more externally (Neville Duke, pers. comm.; Epstein and Brown 2003). It is worth noting that this morphology and feeding damage on edges and holes caused by late instar Prodidactis is independently derived in other Lepidoptera. This includes caterpillars in Zygaenoidea, which feed externally at leaf edges with retractile heads and a ventral surface that is more closely appressed to the leaf surface (Epstein 1996). Scalelike setae such as those found in Prodidactis and other families including Bucculatricidae and Zygaenidae (Davis 1987, Stehr 1987) may have tactile function for feeding near the edges. These specialized setae have not been reported in Hyblaea or 
Thyrididae. One of the examined Hyblaea larvae had three setae on the lateral pinaculum of T1, on one side only. Such asymmetry is common in Lepidoptera larvae, but it is rarely reported (Mutanen et al. 2007, 2012).

The well-sclerotized pupa of Hyblaea with a distinctive cremaster is typical of Obtectomera (and Gelechioidea), while the pupa is thin-cuticled and lacking a cremaster in Prodidactis, as in many Zygaenoidea (Figs. 19, 20). The thickness of the cuticle and the presence of a cremaster may be correlated with the structure of the cocoon which is flimsy in Hyblaea. After eclosion of the adult, the body parts of the pupal skin loosen to some extent in Zygaenoidea. It is not known whether the pupa of Prodidactis is 'obtect,' i.e., whether abdominal segments 4-6 are movable, or if the body parts loosen after the eclosion of the adult, as the samples available are shrunken with the adult moth inside. The absence of the rows of spines on the dorsum of the abdomen generally characterizes Obtectomera; they are absent in Prodidactis (Fig. 20). Otherwise, the pupal characters are homoplastic and of restricted systematic value.
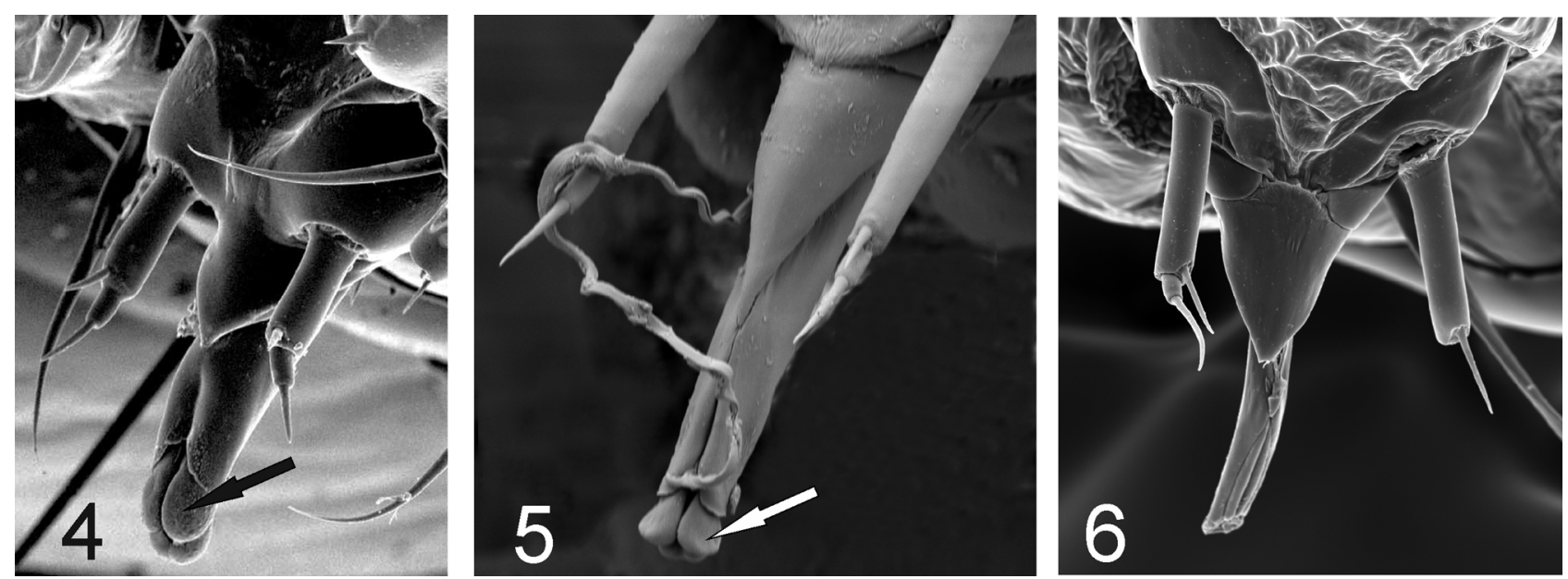

FIGURES 4-6. Spinneret of the larvae of Hyblaeidae, Prodidactidae and Tortricidae. Arrows point at the distal lobes, an apomorphic trait of Hyblaeidae, Prodidactidae and Thyrididae. Fig. 4: Prodidactis mystica. Fig. 5: Hyblaea puera. Fig. 6: Argyrotaenia franciscana (Walsingham), the apex of the spinneret devoid of the lobes.

Of the adult characters, Koning \& Roepke (1949) erroneously state that the external lateral ocellus is absent in Hyblaea (later corrected in Dugdale et al. 1998), and it is absent in Prodidactis. On the wing venation, forewing anal veins are free in Hyblaea - a possible synapomorphy of Hyblaeidae - whereas 1A+2A of the forewing are stalked in Prodidactis as is usual in Lepidoptera. The male genitalia of Hyblaea have a peculiar trifurcate uncus (Koning \& Roepke 1949); the uncus of Prodidactis is a fused single projection that is the prevailing feature across Lepidoptera. The genitalia of Hyblaea and Prodidactis also differ in the shape of the sacculus, which is unmodified in Prodidactis, whereas it has a distal tooth in Hyblaea. Both Hyblaea and Prodidactis have a saclike lobe on the hind coxa. We searched unsuccessfully for this trait on representatives of Copromorphidae, Thyridoidea and Calliduloidea, and this structure is not otherwise reported in any other Lepidoptera. The males of Hyblaea have a hair pencil in the hind tibia; according to Epstein and Brown (2003), the male of Prodidactis has a hair pencil in connection of the coxal lobes. The much reduced labial palpi characteristic of Prodidactis are different from those of Hyblaea whose labial palpi are relatively long and porrect. The head of Hyblaea is disproportionately narrow compared to the width of the thorax (Fig. 21), whereas the head is of usual dimensions in Prodidactis (Fig. 22). It should be noted, however, that the thorax of Prodidactis is slenderer than that of Hyblaea, so this feature cannot be directly compared between these taxa.

To summarize, most of the characteristics considered above appear to be homoplastic in Apoditrysia (but see the condition of setae of prothoracic L group discussed above), thus generally do not link Prodidactis to Hyblaeidae in a convincing manner. However, the peculiar modifications of the adult hind coxa (Figs. 1-3) and larval spinneret (Figs 4-6) are, to our knowledge, unique in Lepidoptera, the former found only in Hyblaeidae and Prodidactis, the latter only in Hyblaeidae, Prodidactis and Thyridoidea. Thus, there seems to be two strong synapomorphies against a number of homoplastic features. These alone could suffice to suggest that Hyblaeidae, Prodidactis, and Thyrididae are related, in the absence of any strong contradictory traits. For discussion of the possible relationship between Hyblaeoidea and Thyridoidea, see Dugdale et al. (1998). 

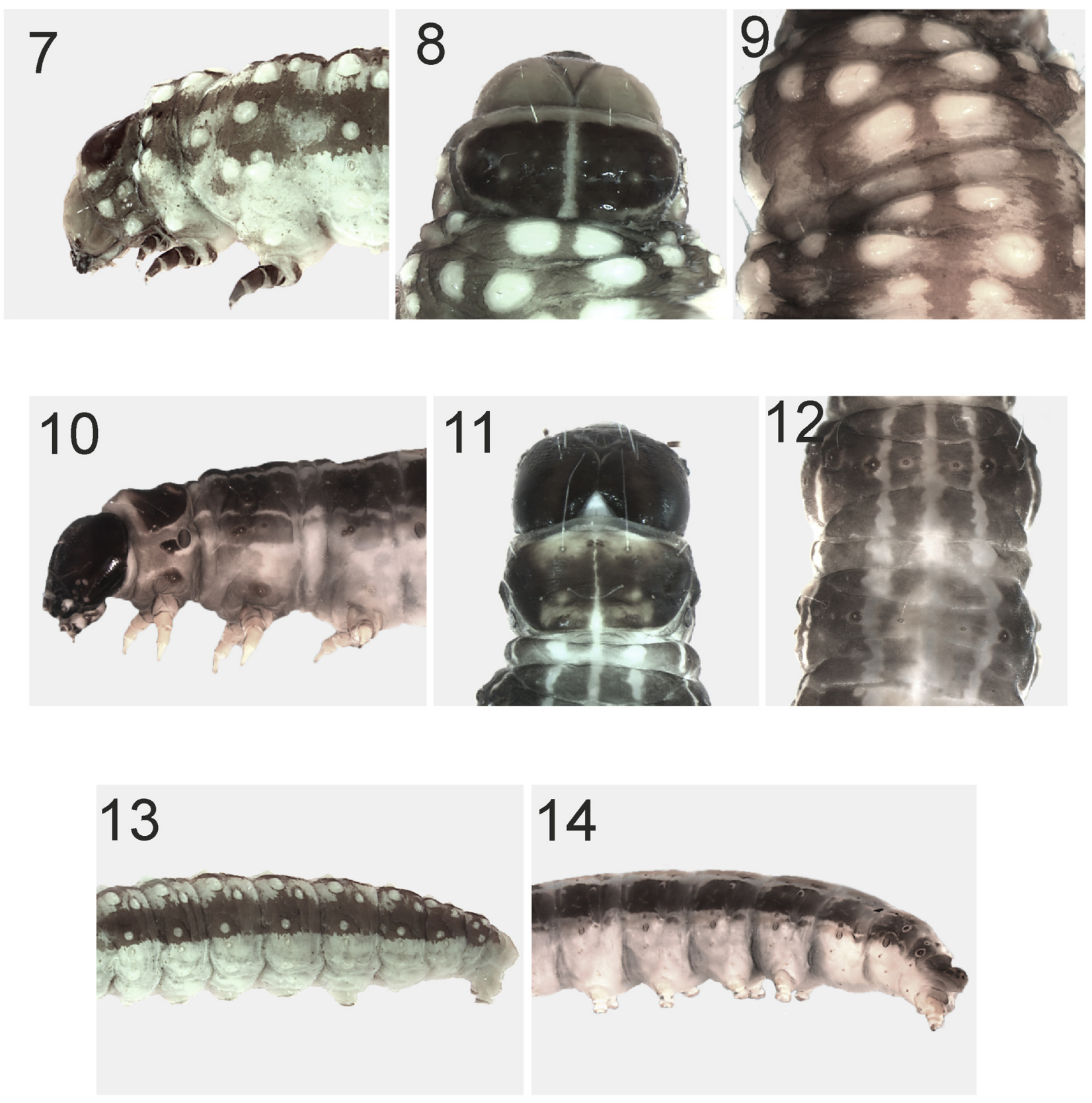

FIGURES 7-14. Details of larvae of Prodidactis mystica and Hyblaea puera. Figs 7-9: P. mystica; Fig. 7: head and thorax in lateral view; Fig. 8: head and thorax in dorsal view; Fig. 9: thorax in dorsal view showing the large pinacula. Figs 10-12: $H$. puera; Fig. 10: head and thorax in lateral view; Fig. 11: head and thorax in dorsal view; Fig. 12: thorax in dorsal view showing the absence of prominent pinacula. Fig. 13. Abdomen of P. mystica in lateral view. Fig. 14. Abdomen of H. puera in lateral view.

To evaluate this hypothesis, we attempted to sequence 8 genes (6157 base pairs) from two dry specimens of Prodidactis mystica obtained from Kenya (in 2010) and Tanzania (in 2005). The specimen from Kenya provided successful amplification of 5 genes (COI, CAD, EF-1a, MDH and wingless) for a total of 3295 bases, whereas the specimen from Tanzania had more degraded DNA and was not included in the analyses. Sequences are available at GenBank under accession numbers KF110732-KF110739. We used the data set of Mutanen et al. (2010) as the basis of analyses. Datasets comprising 105, 264 and 370 representative species of ditrysian Lepidoptera were analysed using maximum likelihood methods. The largest dataset was the same as applied in Mutanen et al. (2010) supplemented with 19 taxa sequenced after publication of this study. Of these, the member of Copromorphidae, 
Copromorpha lichenitis (Turner), could be considered as potentially the most significant addition in terms of phylogenetic affinities of Prodidactis. The dataset with 264 species was similar, but with many presumably less relevant taxa excluded, notably non-Ditrysian Lepidoptera and superfluous representatives of species rich taxa (e.g. Noctuoidea). The taxon set with 105 members was constructed on the basis of having a wide phylogenetic representation of ditrysian taxa, but with minimal repeats at the family level and below. Taxon sets were constructed using VoSeq program (Peña \& Malm 2012). Maximum likelihood analyses were done in RAxML version 7.3.2 on the CIPRES Science Gateway (Miller et al. 2010). Node support was estimated with 100-1000 bootstrap replicates. The 105-species dataset was also analysed using Bayesian Inference methods with MrBayes version 3.2 (Ronquist \& Huelsenbeck, 2003) in the web-based portal Bioportal at the University of Oslo (Kumar et al. 2009). For the Bayesian analysis the data were partitioned with the program TIGER (Cummins \& McInerney 2011). This method partitions characters according to the rate of evolution and thus can potentially improve phylogenetic inference. The program was set to partition the data into 10 bins. Two bins ( 2 and 3 ) did not include any characters, and bins 4, 5, 6 and 7 had only under 30 characters each. Following the procedure adopted in Rota and Wahlberg (2012), these were combined with bin 1, which had 2925 characters making the total number of characters in this bin 2985. Bin 8 had 223 characters; bin 9 had 787 characters; and bin 10 had 2161 characters. Models for each of the four partitions were obtained with PartitionFinder (Lanfear et al. 2012). The analyses were run for 30 to 50 million generations, and convergence was determined after the burn-in stage using graphical diagnostics and when the standard deviation of split frequencies reached values between 0.01 and 0.05 .
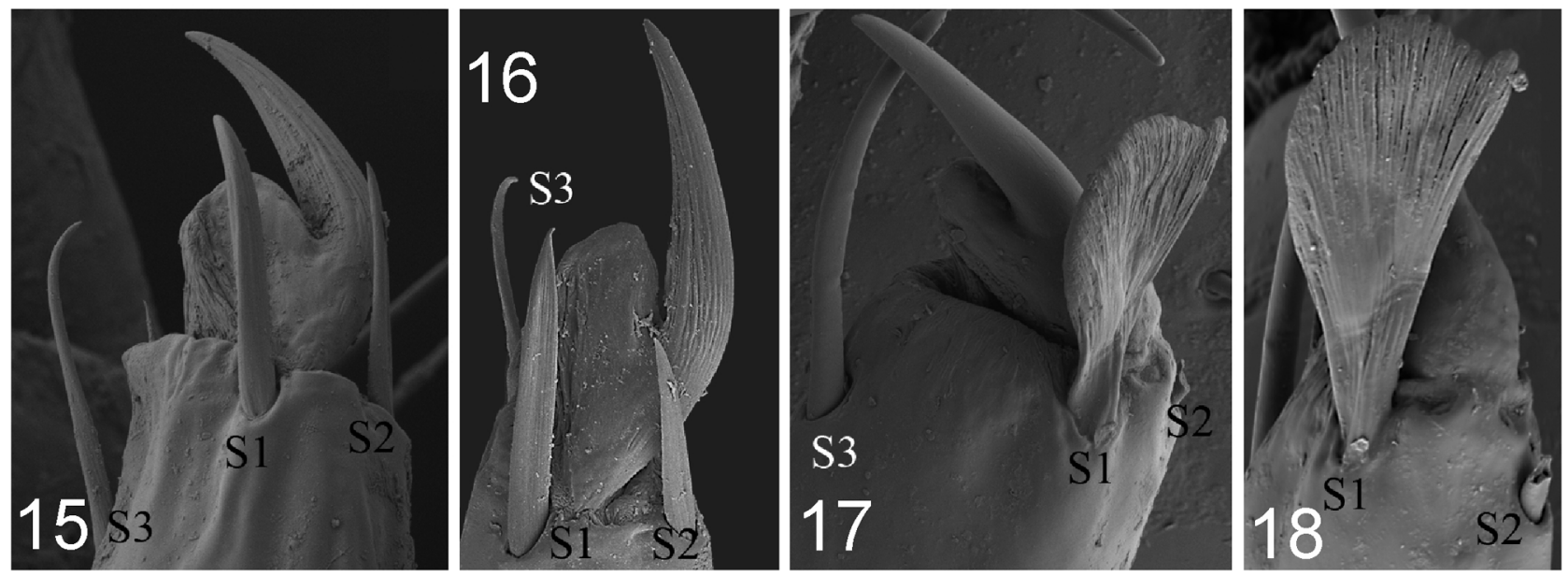

FIGURES 15-18. Claw and the accessory setae of pretarsus of Hyblaea puera and Prodidactis mystica. $\mathrm{S} 1=$ seta $1, \mathrm{~S} 2=$ seta 2, S3 = seta 3, S4 = seta 4. Figs. 15, 16: H. puera; Figs. 17, 18: P. mystica.

In the best trees obtained from the maximum likelihood analyses Prodidactis and Hyblaea are placed as sistertaxa, with bootstrap support values of $46-53 \%$. This relationship was also obtained in the Bayesian analysis (posterior probability 0.53). Copromorpha also showed an association with Hyblaea + Prodidactis. Based on our molecular results Copromorphidae may form a sister group to Hyblaeidae + Prodidactidae, or alternatively may even be a sister group to either of them. The superficial morphological dissimilarity, and more notably, the absence of the hind leg and spinneret modifications in Copromorpha, which are shared between Hyblaeidae and Prodidactidae, would support the sister group relationship between the two latter families and suggest that Thyrididae could also be close. Thyrididae was not found clearly linked to Hyblaeidae, Prodidactis or Copromorphidae, but appears near these, though with negligible support (among, for example Alucitoidea) in our result and those of Regier et al. (2013). Closer morphological scrutiny is certainly warranted to elucidate the possible relationships between Callidulidae, Copromorphidae, Hyblaeidae, Prodidactidae and Thyrididae. 

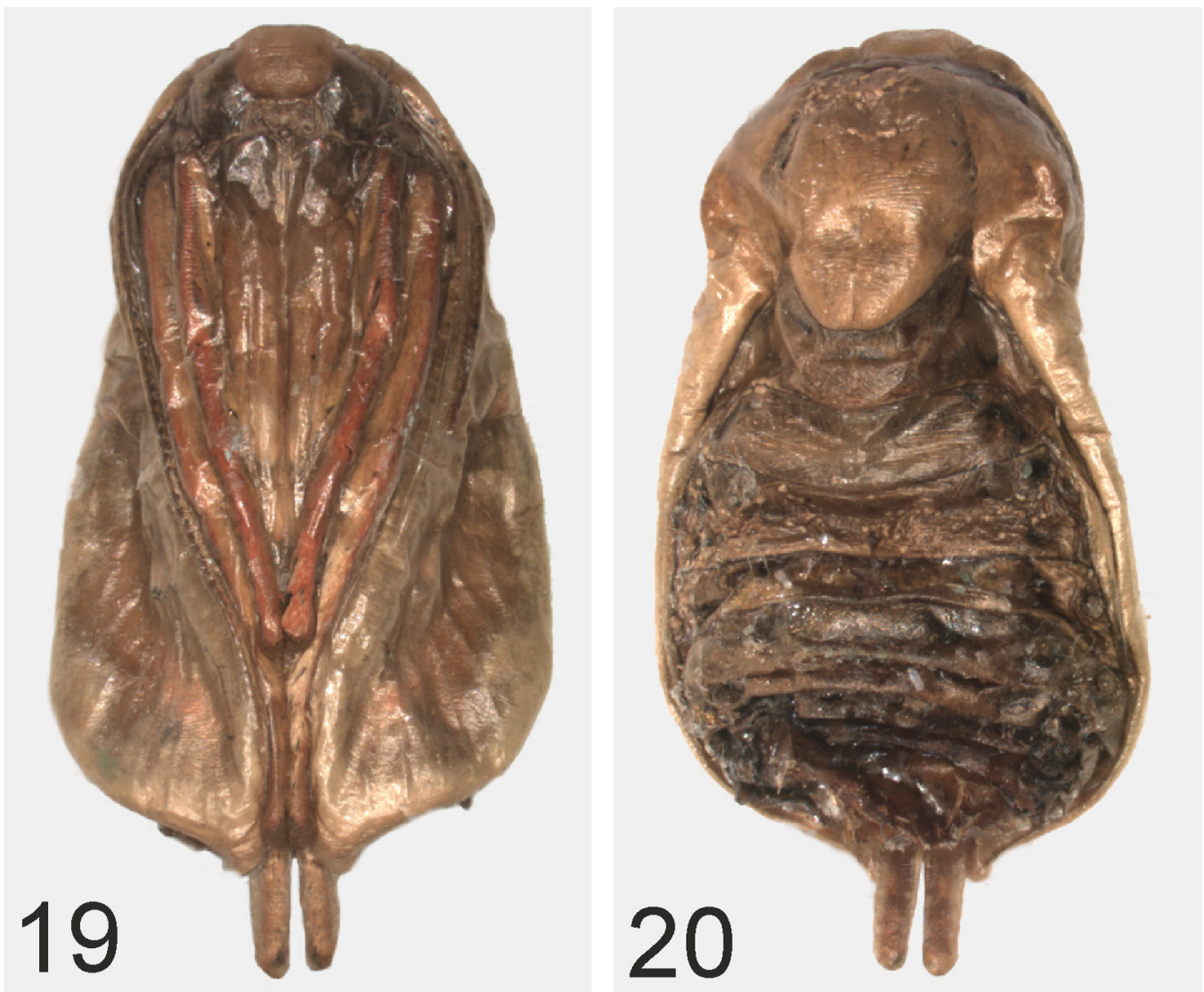

FIGURES 19-20. Pupa of Prodidactis mystica. Fig. 19: ventral view, Fig. 20: dorsal view.
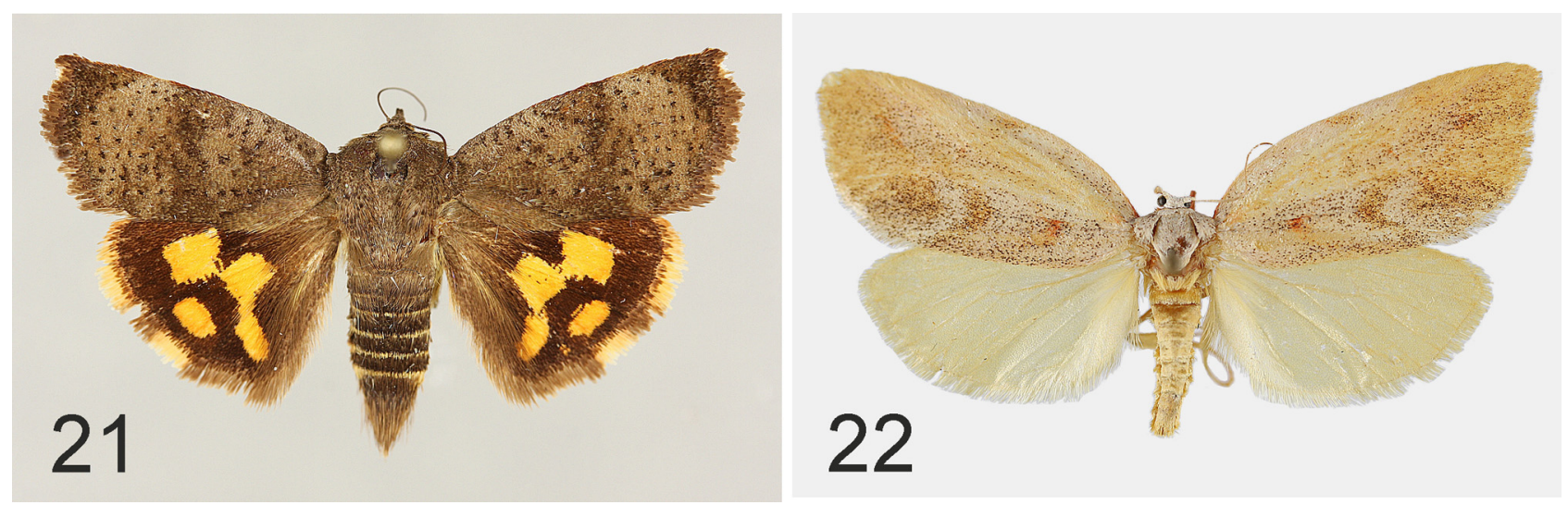

FIGURES 21-22. External appearance of Hyblaea and Prodidactis. Fig. 21: H. fortissima (Butler), Fig. 22: P. mystica (Meyrick).

\section{Conclusions}

On the basis of both morphological and molecular evidence, we conclude that Prodidactis mystica is a relative of Hyblaeidae. Based on the combination of two reliable morphological synapomorphies and molecular evidence, and in the absence of any convincing contradictory evidence, the family Prodidactidae, consisting of a single species, is placed at the superfamily Hyblaeoidea. Both Hyblaeidae and Prodidactidae have their own synapomorphies that are comparable to those of other families. Because these families appear consistently linked in the molecular analyses, we suggest placing Prodidactidae in Hyblaeoidea and maintaining Prodidactidae as its own family. The possible relationship of Thyrididae to Hyblaeidae + Prodidactidae warrants further investigation, as it is supported by the similar modification of the larval spinneret, but is not directly supported by molecular analyses. 
We cordially thank Leif Aarvik (Oslo, Norway), J. W. Brown (Washington, U.S.A), Axel Hausmann (Munich, Germany) and David Lees (London, UK) for kindly providing us specimens of Prodidactis, and Marianne Horak, Ted Edwards and John Heppner for providing material of Hyblaea immatures. We thank other colleagues who have provided support for our research either by providing invaluable specimens or helping other ways.

\section{References}

Cummins, C.A. \& McInerney, J.O. (2011) A method for inferring the rate of evolution of homologous characters that can potentially improve phylogenetic inference, resolve deep divergence and correct systematic biases. Systematic Biology, 60, 833-844.

Davis, D.R. (1987) Lyonetiidae (Tineoidea), In: Stehr, F. W. (ed.) Immature Insects, 1. Dubuque, Iowa. Kendall/Hunt, pp. $370-372$.

Dugdale, J.S., Kristensen, N.P., Robinson, G.S. \& Scoble, M.J. (1998) The smaller Microlepidoptera-grade superfamilies, In: Kristensen, N.P. (ed.) Lepidoptera: Moths and butterflies. Volume 1: Evolution, systematics, and biogeography. Handbuch der Zoologie/Handbook of Zoology. Band/Volume IV Arthropoda: Insecta. Walter de Gruyter GmbH. \& Co. Berlin \& New York, pp. 217-232.

Epstein, M.E. (1996) Revision and phylogeny of the limacodid-group families, with evolutionary studies on slug caterpillars (Lepidoptera: Zygaenoidea). Smithsonian Contributions in Zoology, 582, 1-102.

Epstein, M. \& Brown, J.W. (2003) Early stages of the enigmatic Prodidactis mystica (Meyrick) with comments on its new family assignment (Lepidoptera: Prodidactidae). Zootaxa, 247, 1-16.

Heikkilä, M. \& Kaila, L. (2010) Reassessment of the enigmatic Lepidopteran family Lypusidae (Lepidoptera: Tineoidea; Gelechioidea). Systematic Entomology, 35, 71-89.

Heikkilä, M., Kaila, L., Mutanen, M., Peña \& Wahlberg, N. (2012) Cretaceous origin and repeated tertiary diversification of the redefined butterflies. Proceedings of the Royal Society, B., 279, 1093-1099. http://dx.doi.org/10.1098/rspb.2011.1430

Heppner, J.B. (1998) Classification of Lepidoptera. Part 1. Introduction. Holarctic Lepidoptera, 5 (supplement) 1, 1-148.

Janse, A.J.T. (1964) The moths of South Africa, volume 7. Limacodidae. Transvaal Museum, Pretoria, 136 pp.

Kaila, L., Mutanen, M. \& Nyman, T. (2011) Phylogeny of the mega-diverse Gelechioidea (Lepidoptera): adaptations and determinants of success. Molecular Phylogenetics and Evolution, 61, 801-809. http://dx.doi.org/10.1016/j.ympev.2011.08.016

Karsholt, O., Mutanen, M., Lee, S. \& Kaila, L. (2013) A molecular analysis of the Gelechiidae (Lepidoptera, Gelechioidea) with an interpretative grouping of its taxa. Systematic Entomology, 38, 334-348.

Kawahara, A.Y., Ohshima, I., Kawakita, A., Regier, J.C., Mitter, C., Cummings, M.P., Davis, D.R., Wagner, D.L., De Prins, J. \& Lopez-Vaamonde, C. (2011) Increased gene sampling strengthens support for higher-level groups within leaf-mining moths and relatives (Lepidoptera: Gracillariidae). BMC Evolutionary Biology, 11, 182. http://dx.doi.org/10.1186/1471-2148-11-182.

Koning, H.S. de \& Roepke, W. (1949) Remarks on the morphology of the teak moth Hyblaea puera Cr. (Lep. Hyblaeidae). Treubia, 20, 25-30.

Kristensen, N.P. (Ed.) (1998) Lepidoptera: Moths and butterflies. Volume 1: Evolution, systematics, and biogeography. Handbuch der Zoologie/Handbook of Zoology. Band/Volume IV Arthropoda: Insecta. Walter de Gruyter GmbH. \& Co. Berlin \& New York. 491 pp.

Kumar, S., Skjaeveland, A., Orr, R.J.S., Enger, P., Ruden, T., Mevik, B.H., et al. (2009) AIR: A batch-oriented web program package for construction of supermatrices ready for phylogenomic analyses. BMC Bioinformatics, 10.

Lanfear, R., Calcott, B., Ho, S.Y.W. \& Guindon, S. (2012) PartitionFinder: Combined Selection of Partitioning Schemes and Substitution Models for Phylogenetic Analyses. Molecular Biology and Evolution, 29, 1695-1701.

Meyrick, E. (1918) Exotic Microlepidoptera, 2(6), 161-192.

Meyrick, E. (1921) Descriptions of South African Lepidoptera. Annals of the Transvaal Museum, 8, 49-148.

Meyrick, E. (1930) Exotic Microlepidoptera, 3(18), 545-576.

Miller, M. A., Holder, M. T., Vos, R., Midford, P. E., Liebowitz, T., Chan, L., et al. (2010) The CIPRES Portals. CIPRES. 201301-31. URL:http://www.phylo.org/sub_sections/portal (Accessed 31 Jan. 2013) (Archived by WebCite(r) at http:// www.webcitation.org/5imQ1JeQa)

Minet, J. (1991) Tentative reconstruction of the ditrysian phylogeny (Lepidoptera: Glossata). Entomologica Scandinavica, 22, 69-95.

Mutanen, M., Aarvik, L., Huemer, P., Kaila, L., Karsholt, O. \& Tuck, K. (2012) DNA barcodes reveal that the widespread European tortricid moth Phalonidia manniana (Lepidoptera: Tortricidae is a mixture of two species. Zootaxa, 3262, 1-21.

Mutanen, M., Ruotsalainen, H. \& Kaila, L. (2009) Variation in larval chaeotaxy in Orthosia gothica (Lepidoptera: Noctuidae): effects of mother, sex and side, and implications for systematics. Systematic Entomology, 34, 712-723.

http://dx.doi.org/10.1111/j.1365-3113.2009.00486.x 
Mutanen, M., Wahlberg, N. \& Kaila, L. (2010) Comprehensive gene and taxon coverage elucidates radiation patterns in moths and butterflies. Proceedings of the Royal Society, B., 277, 2839-2848. http://dx.doi.org/10.1111/10.1098/rspb.2010.0392

Nieukerken, E.J. van, Kaila, L., Kitching, I.J., Kristensen, N.P., Lees, D.C., Minet, J., Mitter, C., Mutanen, M., Regier, J.C., Simonsen, T.J., Wahlberg, N., Yen, S.-H., Zahiri, R., Adamski, D., Baixeras, J., Bartsch, D., Bengtsson, B.Å., Brown, J.W., Bucheli, S.R., Davis, D.R, De Prins, J., De Prins, W., Epstein, M.E., Gentili-Poole, P., Gielis, J.C., Hättenschwiler, P., Hausmann, A., Holloway, J.D., Kallies, A., Karsholt, O., Kawahara, A.Y., Koster, J.C., Kozlov, M.V., Lafontaine, J.D., Lamas, G., Landry, J.-F., Lee, S., Nuss, M., Park, K.-T., Penz, C., Rota, J., Schmidt, B.C., Schintlmeister, A., Sohn, J.-S., Solis, M.A., Tarmann, G.M., Warren, A.D., Weller, S., Yakovlev, R.V., Zolotuhin, V.V. \& Zwick, A. (2011) Order Lepidoptera. In: Zhang, Z-Q. (Ed.), Animal biodiversity: An outline of higher-level classification and survey of taxonomic richness. Zootaxa, 3148, 112-121.

Peña, C. \& Malm, T. (2012) VoSeq: A Voucher and DNA Sequence Web Application. PLoS ONE, 7(6), e39071. http://dx.doi.org/10.1371/journal.pone.0039071

Regier, J.C., Brown, J.W., Mitter, C., Baixeras, J., Cho, S., Cummings, M.P. \& Zwick, A. (2012) A molecular phylogeny for the leaf-roller moths (Lepidoptera: Tortricidae) and its implications for classifications and life history evolution. PloS ONE 7(4), e35574. http://dx.doi.org/10.1371/journal.pone.0035574

Regier, J.C., Mitter, C., Solis, M.A., Hayden, J.E., Landry, B., Nuss, M., Simonsen, T.J., Yen, S.-H., Zwick, A. \& Cummings, M.P. (2012) A molecular phylogeny for the pyralid moths (Lepidoptera: Pyraloidea) and its implications for higher-level classification. Systematic Entomology, 37, 635-656.

Regier, J.C., Mitter, C., Zwick, A, Bazinet, A.L., Cummings, M.P., Kawahara, A.Y., Sohn, J.-C., Zwickl, D.J., Cho, S., Davis, D.R., Baixeras, J., Brown, J., Parr, C., Weller, S., Lees, D.C., Mitter, K.T. (2013) A large-scale, higher-level, molecular phylogenetic study of the insect Order Lepidoptera (moths and butterflies). PLOS ONE 8(3), e58568. http://dx.doi.org/10.1371/journal.pone.0058568

Ronquist, F. \& Huelsenbeck, J.P. (2003) MrBayes 3: Bayesian phylogenetic inference under mixed models. Bioinformatics, 19, $1572-1574$.

Rota, J. (2011) Data partitioning in Bayesian analysis: molecular phylogenetics of metalmark moths (Lepidoptera: Choreutidae). Systematic Entomology, 36, 317-329.

Rota, J., \& Kristensen, N.P. (2011) Note on taxonomic history, thoraco-abdominal articulation, and current placement of Millieriidae (Insecta: Lepidoptera). Zootaxa, 3032, 65-68.

Rota, J. \& Wahlberg, N. (2012) Exploration of data partitioning in an eight-gene dataset: phylogeny of metalmark moths (Lepidoptera, Choreutidae). Zoologica Scripta, 41, 536-546. http://dx.doi.org/10.1111/j.1463-6409.2012.00551.x

Sihvonen, P., Mutanen, M., Kaila, L., Brehm, G., Hausmann, A. \& Staude, H. (2011) Comprehensive molecular sampling yields a robust phylogeny for geometrid moths (Lepidoptera: Geometridae). PLoS ONE 6(6), e20356. http://dx.doi.org/10.1371/journal.pone.0020356

Simonsen, T.J., de Jong, R., Heikkilä, M. \& Kaila, L. (2012) Butterfly morphology in a molecular age - does it still matter in butterfly systematics? Arthropod Structure \& Development, 41, 307-322.

Sohn, J.-C., Regier, J.C., Mitter, C., Davis, D., Landry, J.-F., Zwick, A. \& Cummings, M.P. (2013) A molecular phylogeny for Yponomeutoidea (Insecta, Lepidoptera, Ditrysia) and its implications for classification, biogeography and the evolution of host plant use. PLOS ONE 8(1), e55066. http://dx.doi.org/10.1371/journal.pone.0055066

Stehr, F.W. (1987) Zygaenidae (Zygaenoidea). In: Stehr, F.W. (ed.) Immature Insects, 1. Dubuque, Iowa. Kendall/Hunt, pp. $453-454$.

Wahlberg, N., Braby, M.F., Brower, A.V.Z., de Kong, R., Lee, M.M., Nylin, S., Pierce, N.E., Sperling, F.A.H., Vila, R., Warren, A.D. \& Zakharov, E. (2005) Synergistic effects of combining morphological and molecular data in resolving the phylogeny of butterflies and skippers. Proceedings of the Royal Society, B., 1572, 1577-1586. http://dx.doi.org/10.1098/rspb.2005.3124

Zahiri, R., Holloway, J.D., Kitching, I.J., Lafontaine, J.D., Mutanen, M. \& Wahlberg, N. (2012) Molecular phylogenetics of Erebidae (Lepidoptera, Noctuoidea). Systematic Entomology, 37, 102-124. http://dx.doi.org/10.1111/j.1365-3113.2011.00607.x

Zahiri, R., Kitching, I.J., Lafontaine, J.D., Mutanen, M., Kaila, L., Holloway, J.D. \& Wahlberg, N. (2010). A new molecular phylogeny offers hope for a stable family level classification of the Noctuoidea (Lepidoptera). Zoologica Scripta, 40, $158-173$.

Zahiri, R., Lafontaine, J.D., Holloway, J.D., Kithing, I.J., Schmidt, B., Kaila, L. \& Wahlberg, N. (2013) Major lineages of Nolidae (Lepidoptera, Noctuoidea) elucidated by molecular phylogenetics. Cladistics, 29, 337-359.

Zwick, A. (2006) Phylogenetic analyses and taxonomy of Anthelidae (Lepidoptera). Ph.D.thesis, The Australian National University, Canberra, Australia.

Zwick, A. (2008) Molecular phylogeny of Anthelidae and other bombycoid taxa (Lepidoptera: Bombycoidea). Systematic Entomology, 33, 190-209. http://dx.doi.org/10.1111/j.1365-3113.2007.00410.x

Zwick, A., Regier, J.C., Mitter, C. \& Cummings, M.P. (2011) Increased gene sampling yields robust support for higher-level clades within Bombycoidea (Lepidoptera). Systematic Entomology, 36, 31-43.

http://dx.doi.org/10.1111/j.1365-3113.2010.00543.x 